\title{
The Cell Membrane: A Historical Narration
}

\section{Hücre Membranının Keşfi: Tarihsel Bir Bakış}

\author{
(i) Kübra Tuğçe KALKAN, iD Mukaddes EŞREFOĞLU
}

Bezmialem Vakıf University Faculty of Medicine, Department of Histology and Embryology, İstanbul, Turkey

\begin{abstract}
The discovery of the structural elements of the cell has been entirely dependent on technological inventions. Although the discovery of cell membranes is thought to be in parallel with the discovery of microscopes, this is not exactly true. In the early 1660 s, Robert Hooke made his first observation using a light microscope. In 1665, he examined a piece of fungus under a light microscope and he called each space as "cellula". It was not already possible for him to see cell membranes with the primitive light microscope he used in this study. Also because the cells he was trying to study were plant cells, the lines that actually bounded the "cellula" were not the cell membrane, but the cell wall.In the following years, in addition to the microscopic observations, various physio-chemical studies were done in order to explore the structural and functional properties of the plasma membranes. In this review, the historical journey of the plasma membrane was summarized.
\end{abstract}

Keywords: Plasma membrane, history, light microscope

\section{ÖZ}

Hücrenin yapısal elemanlarının keşfi tamamen teknolojik buluşlara bağımlı olmuştur. Her ne kadar hücre membranlarının keşfinin mikroskopların keşfiyle paralel olduğu düşünülse de bu tam olarak doğru değildir. Bin altı yüz altmışlı yılların başında Robert Hooke ilk ışık mikroskobik gözlemini gerçekleştirmiştir. 1665 yılında ışık mikroskop altında bir mantar parçasını inceleyerek gördüğü boşlukları "cellula" olarak isimlendirmiştir. Bu incelemede kullandığı ilkel ışık mikroskobu ile hücre membranlarını görmesi zaten mümkün değildi. Ayrıca incelemeye çalıştığı hücreler bitki hücreleri olduğu için, aslında hücreleri sınırlayan çizgiler hücre membranı değil, hücre duvarıydı. İlerleyen yıllarda mikroskobik gözlemlere ilaveten çeşitli fizyokimyasal çalışmalarla hücre membranlarının yapısal ve fonksiyonel özellikleri açıklanmaya çalışıldı. Bu derlemede hücre membranlarının keşfi ile ilgili çalışmalar tarihsel bir bakış açısı ile özetlenmiştir.

Anahtar Sözcükler: Hücre membranı, mikroskobi, tarih

\section{Introduction}

Molecular Properties of Cell Membrane: Eukaryotic cells are surrounded by cell membranes consisting of various molecules (1). In addition to protecting cells from various harmful factors, cell membranes create a regulated internal environment. The main components of membranes are phospholipids, proteins and carbohydrates. A double layer of phospholipids forms the main membrane skeleton. Proteins can be found either sprinkled inside this layer or clinging to the outer faces. Carbohydrate molecules cling to integral proteins or phospholipids (2). The current membrane model describing the structure and functions of membranes is the "Fluid mosaic model" (Figure 1). This description was first used by Singer and Nicolson (3) in the early 1970s. The fluid mosaic model has been modified by various researchers after its initial identification and has become the final form that is valid today (1). 
According to the fluid mosaic model, membranes are basically composed of lipids, proteins and carbohydrates. The main skeleton of the membranes is formed by phospholipids, which are organized into two layers. Each phospholipid molecule has one hydrophilic and one hydrophobic region (4). The hydrophobic region or apolar region of each molecule is located facing the center of the membrane. Conversely, hydrophilic tip settles facing out of the layer (5). Membrane proteins are classified according to their location. One of these, integral membrane proteins (also called intrinsic proteins), is fully or partially embedded in the phospholipid layer. Integral membrane proteins that move across the membrane and extend from one end of the membrane to the other are called "transmembrane proteins". Peripheral membrane proteins (also called extrinsic proteins) hold onto the surfaces of the membrane temporarily by weak connections. According to the fluid mosaic model, the third main element of the membrane is carbohydrates. These molecules form glycoproteins by clinging to proteins and glycolipids by clinging to lipids (6). There are many important features described by Singer and Nicolson (3) in relation to the fluid mosaic model. Some of these are fluidity, viscosity, continuity and asymmetry. Due to its fluidity property, molecules in the membrane can move in the lateral or vertical direction (7). The movement of molecules is regulated in such a way as to provide an optimum environment for the full function of membrane-bound enzymes and receptors, thanks to the viscosity, which is defined as the resistance of a liquid to flow. Membrane viscosity may vary according to the arrangement of membrane components $(3,8)$. The inner and outer media are selectively separated from each other by means of continuity, which is another membrane feature, and a regulated inner environment is created. Thus, the integrity of the cell is maintained (3). Asymmetry is a natural result of asymmetric placement of membrane components including phospholipids, proteins (structural, enzyme-specific or receptor-qualified proteins) and carbohydrates (9).

Membranes are seen as three layers at the electron microscopic level. In the middle of the two dense layers located on the outside is a less dense third layer. This appearance of membrane is called "unit membrane". This view is entirely related to the arrangement of membrane molecules (Figure 1).

History of Cell Membranes: Before the discovery of the cell and membranes, the discovery of systems to display these structures was necessary. The first in history was in 1590 when Zacharias Jansen, a German eyewear manufacturer, invented a prototype light microscope (10). Nineteen years after that, Galileo Galilei, an Italian scientist, made a light microscope (11). Despite the invention of the microscope, viewing the cells took place years later. For identification of the cell membrane, a wide variety of research has been done between the $16^{\text {th }}$ and $19^{\text {th }}$ centuries (12). The great scientist considered to be the father of optics is Robert Hooke (13). Microscopically, he studied plants, molds, sands and fleas. He discovered the cell and named it. He also pioneered the studies of elasticity. He made significant contributions to the fields of physics, chemistry, meteorology, geology and biology (14). In the early 1660s, together with Robert Hooke, Christopher Wren, Thomas Willis and several other researchers in the Oxford experimental group, they made their first observations using a light microscope. Hooke emigrated to London in 1663, where he began writing his novel "Micrographia" (15). In 1665, while examining a piece of fungus under a light microscope, he saw gaps and gave them the name "cellula", which naturally meaned space (16). Six years after the publication of the book "Micrographia", two important papers were sent to the Royal Society of London by the English botanist Nehemiah Grew (1641-1712) $(17,18)$ and the Italian anatomist Marcello Malpighi (1628-1694) (19). Unbeknownst to each other, these two scientists had described the micro-anatomy of plants. Malpighi had also described the micro-anatomy of animal cells. Because the cell structures of plants were more prominent than those of animals, initial investigations were conducted in plants (20).

In 1672, Nehemiah Grew made the description of "mass of bubbles" in relation to plant parenchyma (17). In 1682 he reported that the cell membrane resembled a lace-like material (18). In Grew's view, not only the fibers in the tissue but also the gaps between the fibers were consistent with each other. During the same period, he suggested that the plant cell wall was an uninterrupted layer that enveloped the cell (21). Malpighi predicted that cells were not simply distances located between membranes, but separate units surrounded by the cell wall $(19,12)$. The strongest supporter of Grew's view was the French botanist Brissseau de Mirbel. This researcher also acknowledged that both plant cavities and their fibers showed continuity, that all plant organisms had membrane systems, and that the cells observed between membranes were parts of this continuum

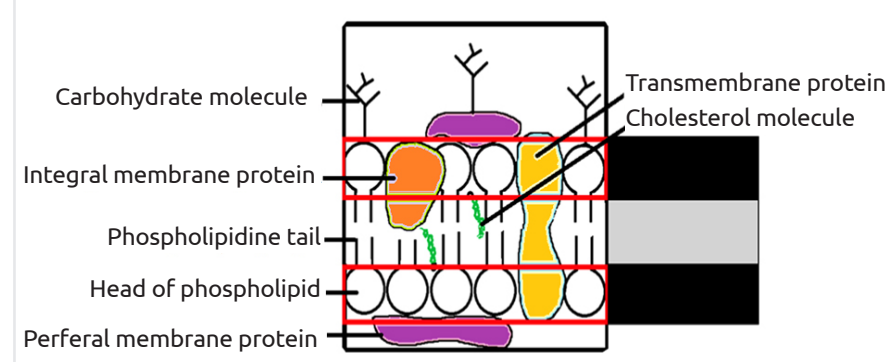

Figure 1. The relationship of membrane molecules with the three-layer unit membrane structure is clearly seen. The outer dark regions correspond to the hydrophilic heads of phospholipid molecules, while the lighter region in the middle corresponds to the hydrophobic tail regions of these molecules. Proteins are found in the membrane or on the periphery of the membrane; carbohydrates can be found bound on proteins or lipids (Illustration: M. Eșrefoğlu) 
Table 1. Only a fraction of membrane-related studies have been shown (Table: M. Eşrefoğlu)

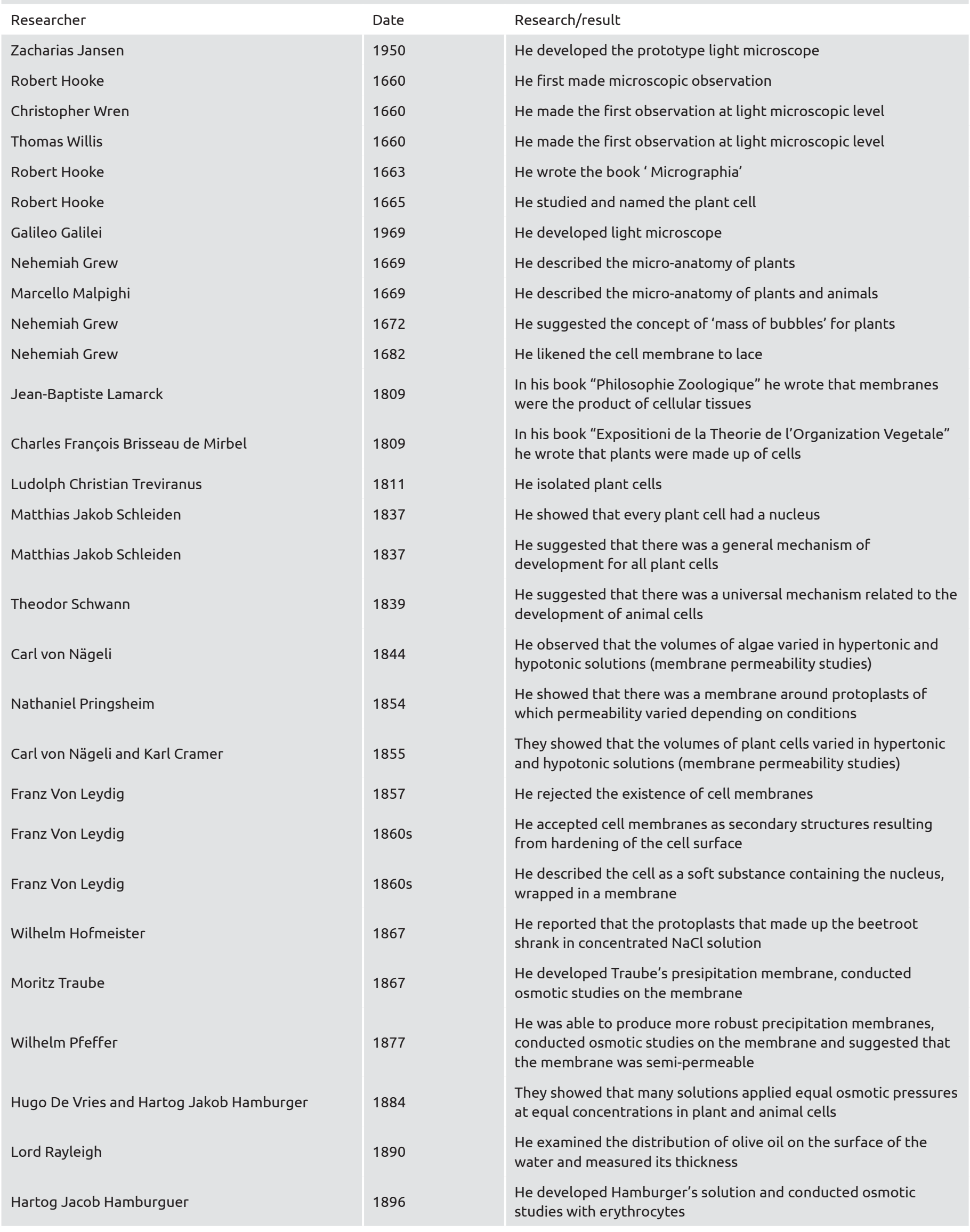


Table 1 contiuned

Charles Ernest Overton

1899

Nathanson

Irving Langmuir

Fricke

Evert Gorter and Francoise Grendel

Harvey and Kennet S. Cole

James Frederic Danielli and Hugh Davson Fricke

James Danielli and Hugh Davson

James Danielli

J. David Robertson

Brady RO and Trams EG

Seymour Jonathan Singer and Garth L. Nicolson
1904

1917

1932

1935

1935

1936

1959

1964

1972
He showed that the membrane was in lipid structure, conducted studies on necrosis and became the first "membranologist"

He proposed the mosaic membrane theory

He showed that hydrocarbon chains were flexibile, not spread flat on the surface of the water, but curled. His study was fundamental to understanding the bilayer structure of the cell membrane

He calculated that the cell membrane was only 4-nm thick

They dissociated lipids from the erythrocyte membrane, suggesting the molecules could make double or single layers

They suggested the membrane was surrounded by proteins

They developed the "Paucimolecular" membrane model

They developed the sandwich membrane model

He developed a series of additional membrane models

He identified the unit membrane and its corresponding molecules (though not exactly accurate) by electron microscopic examination

They described some properties of the current membrane model (proteins enter the lipid layer, the membrane is fluid, etc.)

They proposed Singer and Nicholson's fluid mosaic membrane model structure (20). In the $2^{\text {nd }}$ edition of the book "Philosophie Zoologique" prepared by Lamarck in the early 1800 s, one section was reserved for cellular tissue. In this section, Lamarck wrote: "Membranes, known for many years to form the covering of the brain, nerves, all types of veins, glands, organs, muscles and muscle fibers, and even the skin of the body, are products of cellular tissues in general” (22). Charles François Brisseau de Mirbel published the $2^{\text {nd }}$ edition of his book "Expositioni de la Theorie de l'Organization Vegetale" in 1809 when Lamarck's book was published. The general conclusion of this book was: "Plants are composed of cells, and all sections are caused by membranous tissue that is continuous with each other" (23). This hypothesis finally gained acceptance at the beginning of the $19^{\text {th }}$ century when Treviranus, Moldenhawer and Dutrochet managed to separate plant cells using different methods century (12). Ludolph Christian Treviranus (24) and Johann Jacob Paul Moldenhawer (25) claimed that the cells were individually separable units. All opinions enabled Henri Dutrochet to form the basic doctrine of the modern cell theory. According to this, "Cells are the basic elements of organization" (26). Johann Heinrich Friedrich Link stated that pigments could not pass from one cell to the neighboring cell unless the cell wall broke down. This opinion contradicted Mirbel's view that the gaps were continuous (12,27). Seeing the limits of most living cells except mature plant cells was unlikely at the light microscopic level (28). It was extremely difficult to detect the fine structure of cells with primitive light microscopes at that times. A large number of studies were done in the 1800 s, especially with plant cells. Matthias Jakob Schleiden (1804-1881), a Hamburg-born botanist, shifted the focus of plant Studies from classification research to structural research. Schleiden suggested that each plant cell had a nucleus, which was evidence of the cell's existence. In 1837 Schleiden adopted the idea that there was a general mechanism of development for all plant cells (29). In 1838, while Schleiden and Theodor Schwann enjoyed sipping their coffee after dinner, Schleiden began excitedly talking about the universality of plant cells. Theodor Schwann, born in Neuss in 1810, was a professor of physiology at the University of Louvain. Schwann suddenly realized how much Schleiden's work resembled his own. He himself had observed that all the species he was working on were composed of distinguishable units or cells (28). In 1839, Schwann adapted Schleiden's hypothesis to animal cells, suggesting that there was a universal mechanism related to cell development (30). Several contradictory opinions have been raised over the years following Robert Hooke's miraculous description of the cell. The fact that animal cells did not contain the cell wall seen in plant cells, even though they contained nuclei and protoplasm, caused confusion about the definition of cell (31).

In the early 1890 s, cell membranes were generally considered 
to be mandatory or elective secondary structures. In 1857, the first author to explicitly reject the existence of cell membranes was Franz Von Leydig. Leydig then reassessed cells and cellular structures as a result of a series of observations $(12,32)$. He described the cell as a soft substance containing the nucleus, wrapped in a membrane (33). He attributed this view to the fact that membranes were not always visible. He simply depicted the cell as "A substance resembling a sphere in shape, with an object called a nucleus in its middle" (12). He considered cell membranes to be secondary structures caused by hardening of the cell surface. In these times, various methods were used to show the presence of cell membranes. These methods were generally osmotic study methods that assumed that cell membranes were semi-permeable (34).

In 1844, Carl von Nägeli and observed that protoplasts of some algae (e.g. Nitella and Bryopsis) moved away from their walls when placed in various condensed solutions, and when dilute solutions replaced condensed solutions, they returned back to their former size. Nägeli and Nathaniel Pringsheim (1854), who understood that protoplasts had osmotic properties which were defined for animal bladder by Jean-Antoine Nollet and Henri Dutroched, concluded that there must be a membrane around protoplasts whose permeability varies depending on conditions (33). In the second half of the 19th century, a simple experimental idea launched a new hypothesis regarding cell boundaries (35). In 1855, Nägeli and Karl Cramer reported their observation that when plant cells were put into a hypertonic solution, they shrinked and the protoplasm moved away from the cell wall. On the contrary, when they were put into a hypotonic solution, the cytosol swelled and almost burst (36). In 1867, Wilhelm Hofmeister reported that the protoplasts forming the beetroot shrink in concentrated $\mathrm{NaCl}$ solution. Soon after, Hugo de Vries conducted similar plasmolytic studies in Tradescantia discolor epidermal cells. He also observed protoplasts moving away from the cell wall during the experiment. Hugo de Vries called this event "plasmolysis" (33). Not long after, another German scientist, Hartog Jakob Hamburger studied the entrance and exit of water into red blood cells based on the osmotic pressure of the solution in which they were found. He specifically investigated the effects of dilution leading to hemolysis at the last point. Osmotic studies, which took place in a similar way over time, began to be done more. In 1884, Hugo de Vries and Hamburguer succeeded in using plant and animal cell models to show that many solutions applied equal osmotic pressures at equal concentrations (37). Although today the analysis of these results seemed to be very simple, at that time it was not considered decisive as the membranes still could not be displayed (12).

In 1867 , Moritz Traube designed special membranes to create "artificial cells" with the aim of studying events such as growth and osmosis in living cells (33). The "Traube precipitation membrane' contained molecules at the interface of a potassium ferrocyanide solution and a copper sulfate solution. This membrane was semi-permeable. Traube cells were able to spread rapidly towards bud-like living cells, but the artificial membranes were not strong enough to resist the osmotic pressure that arose within them. They were therefore easily disintegrated. Working to overcome this problem, Wilhelm Pfeffer was able to produce more robust precipitation membranes in 1877 . He conducted a series of experiments explaining the connection between these membranes and osmotic pressure, concentration and temperature of the solution (38). In 1877 Pfeffer, a botanist, was influenced by physiochemical studies and suggested that a plasma membrane or skin covered the outer face of the protoplasm (33). Accoding to this scientist's idea, the membrane he was referring to was similar to the artificial membrane. Pfeffer concluded that the cell barrier must be thin and semi-permeable with data from his studies on the osmotic properties of plasma membranes that have not yet been imaged (39). With these results he revealed that the barrier acted like an invisible skin, allowing water to selectively freely pass into and out of the cell, but limiting the passage of salt and sugar (40). In 1896, the German physiologist Hartog Jacob Hamburguer invented a crystalloid solution (normal saline solution), which took the name "Hamburger's solution". This salt solution, thought to be in osmolality equal to human blood, did not naturally lead to hemolysis in red blood cells (37). Nearly 20 years after Wilhelm Pfeffer came up with his ideas, Overton showed that the permeability barrier -the cell membrane- was in the lipid structure. Charles Ernest Overton (1899) was regarded as the first true 'membranologist' with this view. Overton's main work on understanding membranes was permeability studies (40). Overton carried out many important studies in this area. According to this scientist, a saturated outer boundary layer of a cell was the determinant of the osmotic properties of a living cell. Active events related to diffusion and metabolism played a role in the exchange of soluble matter between the cell and its environment. $\mathrm{Na} / \mathrm{P}$ exchange was important in muscle and nerve stimulation. Overton also added important milestones to science about the theory of necrosis. In times when Overton did these studies, physics studies for cell surface properties in addition to the plasmolysis studies were also developing (40). In the late 1700s, Benjamin Franklin described for the first time that a drop of oil was emitted on the surface of the water in the form of a thin layer (35). In 1890 Lord Rayleigh observed the movement of olive oil on the water surface and estimated the thickness of this layer to be 10-20 $\AA$ (41). Agnes Pockels, a German pioneer in chemistry, conducted experiments using kitchen bowls, wires and buttons in the kitchen sink. He developed his own device to precisely measure the thickness of the oil layer on the water surface (42). In 1904 Nathanson put forward a mosaic membrane theory. According to this theory, the cell membrane was not a simple membrane, but rather contained mosaic domains with properties similar to Traube's presipitation membrane (artificial 
membrane). Such a mosaic membrane could provide different pathways for the entry of soluble or insoluble materials (43).

Development of the Unit Membrane Model: In 1917, Irving Langmuir discovered that with the help of a decoy, the oil molecules spontaneously spread across the water and air interfaces. By measuring the thickness of this layer, he presented the first evidence that this area had a monomolecular characteristic. In an excellent article on the subject, he stated that the propagation in this way created a monomolecular layer on the surface of the water. He calculated the field of each molecule with a simple arithmetic. He also showed that hydrocarbon chains were flexibile, not spread flat on the water surface, but rather curle. This study was fundamental to understanding the bilayer structure of the cell membrane. Langmuir membranes were a key model of experimentation with historical characteristics associated with our modern perspective of biological membranes. In 1925, Evert Gorter and Francoise Grendel dissociated lipids from red blood cells. They calculated that the surface area of the lipid molecules they decomposed was about twice the surface area of the cells themselves. They showed that molecules could make single or double layers (45). The work of these scientists made the concept of the lipid double layer popular at the time. It also opened the door to the identification of the molecular structure of the membrane.

Studies on the membrane continued between 1920 and 1930. Fricke showed that the cell membrane was only 4-nm thick in his study on the measurement of the resistance of the cell membrane. As a result of their studies of membrane surface resistance in various cells, Harvey and Cole suggested that the membrane surface was not bare, but rather surrounded by proteins. This model was detailed in a review article by Danielli and Davson in 1935. In 1935, James Frederic Danielli and Hugh Davson Fricke developed a 'paucimolecular' model, in which molecular details were kept to a minimum by compiling the results of Gorter, Grendel and other scientists. Danielli and Davson proposed that there was a nonpolar lipoid center between the bilayer amphipathic lipoid molecules in the model. They noted that on both sides of the membrane there were protein layers at least one molecule thick above the lipoid layer, this placement was due to the inability of proteins to be found stably within the membrane. Danielli and Davson came up with a sandwich membrane model in the same year (Davson-Danielli model or protein--protein model). According to this model, the surfaces were surrounded by a thin layer of protein on both sides. This observation was an important advance in a better understanding of the compositional nature of biological membranes (46). In 1936 Danielli introduced several membrane models in addition to the paucimolecular model he had created. . He divided the membranes into three as continuous, lipoprotein and mosaic membranes. He said that ion transpot in membranes occured depending on pores, a number of ion transporters, and simple diffusion (47). Although electron microscopy was invented in 1930, it was not possible to study cell membranes in detail until the 1950s, when higher resolutions were achieved. The transverse sections of the membranes revealed the three-layer membrane structure known as the 'railway'. In this view, which would later be called "Unit membrane", there was a third layer between the two dense layers which was less dense (Figure 1). At that time, it was not yet known which layer of the unit membrane corresponded to which molecule. In 1959, J. David Robertson evaluated the paucimolecular model and suggested that the dark regions were protein layers, while the open area in the middle was equivalent to the lipid layer. That prediction was not exactly accurate. Robertson renamed the paucimolecular membrane model as the "Unit membrane model". In a review in 1964 , Brady and Trams noted some of the features of the fluid mosaic model that was valid today. In that paper, they reported that the membrane was composed of lipids and proteins, that proteins entered the membrane and that the lipid component was fluid (48). With the development of freeze-breaking techniques and immuno-electron microscopy techniques, scientists identified isolated membrane proteins and membrane-embedded proteins through antibodies. So, Singer and Nicolson introduced the famous fluid mosaic membrane model in 1972. This model is the most important model in membrane science which has changed and developed until today. Although it has not changed much since its identification, it has been modernized and named as "Modified fluid mosaic model" in the light of the newly obtained data. The fluid mosaic model still holds the distinction of being the most explanatory hypothesis in understanding biological membranes. As is known, the word "mosaic" emphasizes that the membrane is composed of various molecules such as phospholipids, proteins and carbohydrates; the word "fluid" refers to the fact that most of these molecules are mobile (49). This model, which developed in the 1970s and whose foundation remained unchanged, will continue to exist until a new proposal is put forward. Future studies on the cell membrane; It will include membrane modifications to improve certain dysfunctions, including membrane signaling, transport, remodeling, and membrane biosynthesis.

Peer-review: Externally peer reviewed.

\section{Authorship Contributions}

Concept: M.E., K.T.K., Design: M.E., K.T.K., Data Collection or Processing: M.E., K.T.K., Analysis or Interpretation: M.E., K.T.K., Literature Search: M.E., K.T.K., Writing: M.E., K.T.K.

Conflict of Interest: No conflict of interest was declared by the authors.

Financial Disclosure: The authors declared that this study received no financial support. 


\section{References}

1. Rothfield LI, editors. Structure and function of biological membranes. New York: Academic Press; 1971.

2. Stryer L. Biochemistry. 4th ed. New York: W.H. Freeman and Company; 1995.

3. Singer SJ, Nicolson GL. The fluid mosaic model of the structure of cell membranes. Science 1972;175:720-31.

4. Tanford C. The hydrophobic effect: formation of micelles and biological membranes. 2nd ed. New York: John Wiley \& Sons; 1973.

5. Vance J, VanceD, editors. Biochemistry of lipids, lipoproteins and membranes. 5th ed. San Diego: Elsevier; 2008.p.1-39.

6. Daleke DL, Lyles JV. Identification and purification of aminophopholipid flippases. Biochem Biophys Acta 2000;1486:10827.

7. Buda C, Dey I, Balogh N, Horvath LI, Maderspach K, Juhasz M, et al. Structural order of membranes and composition of phospholipids in fish brain cells during thermal acclimatization. Proc Natl Acad 1994;91:8234-8.

8. Kung CE, Reed JK. Microviscosity measurements of phospholipid bilayers using uorescent dyes that undergo torsional relaxation. Biochemistry 1986;25:6114-21.

9. Bagatolli LA, Ipsen JH, Simonsen AC, Mouritsen OG. An outlook on organization of lipids in membranes: searching for a realistic connection with the organization of biological membranes. Prog Lipid Res 2010;49:378-89.

10. Disney AN, Hill C, Baker WE. Origin and development of the microscope the royal micrsocopic society. London: Royal Society; 1928.p.89-115.

11. Singer C. The Dawn of Microscopic Discoveries. J Roy Microsc Soc 1915.p.317-40.

12. Baker JR. The Cell theory, a restatement, history and critique. Part II. New York: Garland Publishing; 1988.p.87-108.

13. Hooke R. Micrographia. London: J. Martyn \& J. Allestry; 1665.

14. Settles GS. Schlieren and shadowgraph techniques. Visualizing phenomena in transparent media. Berlin: Springer-Verlag; 2001.

15. Hunter M, Schaffer S, editors. Rhetoric and graphics in Micrographia. Woodbridge: Boydell Press; 1989.

16. Hooke R. Micrographia or some physiological descriptions of minute bodies made by magnifying glasses. London: Royal Society; 1665.

17. Grew N. The anatomy of plants with a general account of vegetation founded there upon. London: Hickman; 1672.

18. Grew N. The anatomy of plants: with an idea of a philosophical history of plants. London: Royal Society; 1682.

19. Malpighi M. Anatomy Plantarum. London: Royal Society; 1675.

20. Baker JR. The Cell theory, a restatement, history and critique. Part III. Quarterly J Micros Sci 1952;93:164.

21. Lefanu WR. Nehemiah Grew, a study and bibliography of his writings. Winchester: St Paul's Bibliographies; 1990.
22. Lamarck JBPA. Philosophie Zoologique. Paris; 1809.

23. Mirbel CF. Exposition de la theorie de l'organisation vegetale. 2nd ed. Paris: Avee 9 planches; 1809.

24. Treviranus LC. Beyträge zur pflanzenphysiologie. Göttingen: Dieterich; 1811.

25. Moldenhawer JJP. Beyträge zur anatomie der pflanzen. Kiel: Wäser; 1812.

26. Dutrochet H. Recherches anatomiques et physiologiques sur la structure intime des animaux et des vegetaux, et sur leur motilite. Paris; 1924.

27. Link DHF. Grundlehren der anatomie und physiologie der pflanzen. Göttingen: Danckwerts; 1807.

28. Schleiden MJ. Beiträge zur phytogenesis. Arch Anat Physiol wiss Med 1838;1:137-76.

29. Schleiden MJ. Contributions to phytogenesis. London: The Sydenham Society; 1847.

30. Schwann T: Microscopical researches into the accordance in the structure and growth of animals and plants. London: The Sydenham Society; 1847.

31. Lawson I. Crafting the microworld: how Robert Hooke constructed knowledge about small things. Notes Rec R Soc Lond 2016;70:2344.

32. Leydig F. Lehrbuch der histologie des menschen und der pflanzen. Frankfurt; 1857.

33. Randy OW. Plant cell biology from astronomy to zoology. San Diego, California 92101-4495,USA Elsevier 2009.pp.16.

34. Harris H. The birth of the cell. London: Yale University Press; 1999.

35. Tanford C. Ben Franklin stilled the waves. Oxford: Oxford University Press; 2004.

36. Von Nägeli CW, Cramer CE. Pflanzenphysiologische untersuchungen. Züric: Bel Friedrich Schluthess; 1855.

37. Hamburguer HJ. De invloed van scheikundige verbindingen op bloedlichaampjes in verband met hare molekulair gewichten. Orderz Ged Physiol Lab Utrecht Hoogs 1884;9:26-42.

38. Pfeffer W. Osmotic investigations. In The modern theory of solution. In: Jones HC, editors. New York \& London: Harper brothers publishers; 1899.

39. Stillwell W. An introductıon to Biological membranes from bilayer to ratfs. 1st ed. London: Elsevier; 2013.

40. Deamer D, Kleinzeller A, Fambrough D, editors. Membrane permeability: 100 years since Ernest Overton. New York: Elsevier; 1999.

41. Rayleigh L. Measurements of the amount of oil necessary in order to check the motions of camphor upon water. Proc R Soc Lond 1889;47:364-67.

42. Pockels A. Surface tension. Nature 1891;43:437-39.

43. Troshin AS. Problems of cell permeability. Oxford: Permagon Press Hill Hall; 1966. 
44. Langmuir I. The constitution and fundamental properties of solids and liquids. J Am Chem Soc 1917;39:1848-906.

45. Gorter E, Grendel F. On bimolecular layers of lipoids on the chromocytes of the blood. J Exp Med 1925;41:439-43.

46. Danielli JF, Davson H. A contribution to the theory of permeability of thin films. J Cell Physiol 1935;5:495-508.
47. Danielli JF. Some properties of lipoid films in relation to the structure of the plasma membrane. J Cell Comp Physiol 1936;7:393-408.

48. Robertson JD. The molecular structure and contact relationships of cell membranes. Prog Biophys Mol Biol 1960;10:343-418.

49. Singer SJ, Nicolson GL. The fluid mosaic model of the structure of cell membranes. Science 1972;175:720-31. 